\begin{tabular}{|c|c|c|c|}
\hline \multirow{2}{*}{$\begin{array}{l}\text { KULTURA } \\
\text { i } \\
\text { SPOLECZENS }\end{array}$} & \multicolumn{2}{|c|}{$\begin{array}{l}\text { POLSKA AKADEMIA NAUK } \\
\text { KOMITET SOCJOLOGII } \\
\text { INSTYTUT STUDIÓW POLITYCZNYCH }\end{array}$} & ISSN 0023-5172 \\
\hline & 2009, nr 4 & KULTURA (?) WIZUALNA & \\
\hline
\end{tabular}

MAGDA LEJZEROWICZ

Akademia Humanistyczna w Pułtusku

\title{
POTRZEBA INTERDYSCYPLINARNOŚCI?
}

Czy interdyscyplinarność jest oczywista we współczesnych naukach społecznych i humanistycznych, a może stanowi ona istotny problem, bez którego rozwiązania rozwój tych nauk będzie ograniczony? Czy warto rozmawiać o interdyscyplinarności? Te pytania, i wiele innych, postawiłam sobie jako uczestnik cyklu seminariów „Interdyscyplinarność w naukach społecznych i humanistycznych - możliwości i ograniczenia" ${ }^{1}$. Interdyscyplinarność jako moda czy

Adres do korespondencji: mag00@poczta.onet.pl

${ }^{1}$ Cykl trzech spotkań seminaryjnych pt. „Interdyscyplinarność w naukach społecznych i humanistycznych - możliwości i ograniczenia”, zorganizowany pod instytucjonalną opieką Wydziału I Nauk Społecznych PAN i Instytutu Filozofii i Socjologii PAN przez prof. Joannę Kurczewską przy współpracy dr Magdy Lejzerowicz i mgr Hanny Mokrzyckiej, obejmował trzy seminaria, które miały dać możliwość spotkania i dyskusji badaczom zajmującym się podobnymi kwestiami. Dotyczyły głównych pól problemowych związanych z interdyscyplinarnością w naukach społecznych i humanistycznych. Na zakres tych pól wskazują tytuły sesji, a także ich patroni:

(1) „Interdyscyplinarność w naukach społecznych i humanistycznych: możliwość czy powinność?” (21 XI 2007). Spotkanie dotyczyło problematyki związanej z definicją pojęcia interdyscyplinarności oraz kwestii multidyscyplinarności, transdyscyplinarności, interdyscyplinarności w dyscyplinach sąsiadujących z socjologią, takich jak kulturoznawstwo, literaturoznawstwo, historia, polonistyka, slawistyka, filozofia. Zostało poświęcone pamięci Stefana Czarnowskiego, polskiego socjologa i historyka kultury, którego siedemdziesiątą rocznicę śmierci właśnie obchodziliśmy.

(2) „Socjologia i jej doświadczenia z interdyscyplinarnością — bilans niesentymentalny” (10 XII 2007). Blok problemowy, który się wydał wart poświęcenia mu odrębnego panelu, to socjologia i jej spotkania z interdyscyplinarnością, dyscypliny pograniczne, związki socjologii z dyscyplinami sąsiadującymi. Patronem spotkania został Stanisław Ossowski, socjolog, ale również filozof i teoretyk kultury, autor powszechnie znanej książki O osobliwościach nauk społecznych.

(3) „Filozofia i socjologia — konteksty akademickie i społeczne” (9 stycznia 2008). Pole zainteresowań uczestników trzeciego spotkania obejmowało relacje filozofii i socjologii, ich wzajemne uwikłania, bliskość dyscyplin czy ich odrębność, współpracę instytucjonalną. Poświęcono je Edmundowi Mokrzyckiemu, socjologowi i filozofowi, uczniowi Stanisława Ossowskiego, autorowi 
konieczność była tam tematem wielu wystąpień, paneliści i dyskutanci zastanawiali się nad zadaniami interdyscyplinarności - czy ma prowadzić do pewnej syntezy, wymiany czy dialogu?

Kwestia interdyscyplinarności jest postrzegana jako konieczność badawcza lub pewna tendencja występująca $w$ podejściach badawczych. Nie można zrealizować porządnych badań nie wykraczając poza własną dyscyplinę, choć co stało się przedmiotem żywej dyskusji - pojawiają się również twierdzenia o niemożności prowadzenia badań interdyscyplinarnych.

Chciałabym tu przedstawić komentarze do części wystąpień, zwrócić uwagę na elementy wspólne, które się w nich pojawiały, jak i odmienne interpretacje pewnych problemów. Zamierzam zwrócić uwagę na te dyskusje toczone podczas seminariów, które szczególnie mnie zainteresowały. Każda sesja poświęcona była określonej problematyce, należy jednak zwrócić uwagę, iż w całym cyklu dominowały kwestie będące przedmiotem dyskusji podczas pierwszego spotkania - „Interdyscyplinarność w naukach społecznych i humanistycznych: możliwość czy powinność?”. Koncentrowano się na próbie odpowiedzi na pytanie o to, czym jest interdyscyplinarność, o jej możliwość w naukach humanistycznych i społecznych ${ }^{2}$.

Interdyscyplinarność w naukach istnieje „od zawsze”, jest to fakt, którego nie zmieni nasze uznanie lub nie. Nie jest możliwe zarówno wprowadzenie zakazu uprawiania nauki w sposób interdyscyplinarny, jak i nakazanie prowadzenia badań $\mathrm{w}$ taki właśnie sposób. Pewne problemy nie wymagają takiego podejścia, rozwiązanie innych nie jest możliwe bez wieloperspektywiczności, bez wychodzenia poza granice własnej dyscypliny. W naukach społecznych istnieje jednak konieczność badań i refleksji multi- czy interdyscyplinarnych mimo trudności w ich realizowaniu, mimo dylematów związanych $z$ badaniami wieloaspektowymi versus specjalistycznymi ${ }^{3}$.

Czym jest interdyscyplinarność współcześnie, czy jest możliwością czy powinnością? Jest swego rodzaju tendencją związaną z modą. Modą jest wtedy, gdy jest używana jako hasło promujące jakąś konkretną wyższą uczelnię i w tej sytuacji pozostaje hasłem nie mającym nic wspólnego z rzeczywistą działalnością badawczą owej uczelni. Interdyscyplinarność nie jest koniecznością, nie jest to typ badań, bez których funkcjonować się nie da. Istnieje natomiast potrzeba interdyscyplinarności $\mathrm{w}$ badaniach ze względu na tendencje panujące

antologii dotyczących uwikłań filozoficznych socjologii, które służyły i służą środowisku filozofów i socjologów do tworzenia płaszczyzny porozumienia, prowadzenia wspólnych projektów.

2 Podstawą komentarza są nagrania sporządzone przeze mnie w trakcie sesji. Cytaty zaś z wypowiedzi uczestników poszczególnych paneli pochodzą z tekstów złożonych do publikacji elektronicznej „Interdyscyplinarność w naukach społecznych i humanistycznych — doświadczenia i projekty” (dostępnej na stronie www.ifispan.waw.pl).

${ }^{3}$ M. Golka, Potrzeby i trudności multi- $i$ interdyscyplinarności, w: „Interdyscyplinarność w naukach społecznych i humanistycznych - doświadczenia i projekty” (www.ifispan.waw.pl). 
we współczesnej humanistyce ${ }^{4}$. Łączone są perspektywy, stosuje się ujęcie holistyczne, nastawienia te dominują w myśleniu o człowieku i kulturze, obecne są na poziomie pewnych działań administracyjnych różnych instytucji, co przejawia się na przykład w tworzeniu zespołów badawczych czy sieci naukowych.

Chciałabym jednakże zwrócić tu uwagę, że formułowano również stanowisko, w myśl którego odrębność metodologiczna kulturoznawstwa, historii idei czy socjologii jest trudna do zdefiniowania, a rozróżnienie dyscyplin ze względu na kategorie, pojęcia, sposoby widzenia to jedynie problemy warsztatowe, które można ominąć czy rozwiązać 5 .

Rozwój wielu, jeśli nie wszystkich, dziedzin nauki następuje poprzez przekraczanie granic między dyscyplinami, tak rozwija się fizyka, chemia, biologia, nauki humanistyczne. Jeśli chcemy mówić o problemach, jakie mamy z badaniami interdyscyplinarnymi, to musimy najpierw określić poziom, na którym problem ten się pojawia, musimy odpowiedzieć na pytanie, czy jest to poziom na przykład metody, języka, poznania, instytucji naukowych, finansowania ${ }^{6}$.

Podkreślenia wymaga wielopoziomowość, wielopłaszczyznowość, wielowarstwowość problemów interdyscyplinarnych, a także to, że problem interdyscyplinarności należy rozpatrywać $\mathrm{w}$ wielu odsłonach. Jest to inny problem, jeśli mówimy o współpracy między historią a socjologią, etnologią, w obrębie nauk społecznych, a inny, jeśli chodzi o współpracę między takimi dziedzinami jak filozofia i socjologia, literaturoznawstwo i socjologia ${ }^{7}$.

Konieczność interdyscyplinarności jako formy współczesnej nauki podkreślił Leszek Koczanowicz (DSW we Wrocławiu). Jest ona integralnie związana $z$ rozwojem dyscyplin naukowych, które pozostając $w$ obrębie własnych granic, nie są w stanie realizować swych zadań, gdyż potrzebują do tego dyscyplin pokrewnych. Jednocześnie mimo tych potrzeb nadal obowiązuje zasada czystości poszczególnych nauk, polegająca choćby na określaniu „specyfiki metod i dziedziny", co pozwala na odróżnienie jednych od drugich. Interdyscyplinarność miała być sposobem na ominięcie tej sprzeczności ${ }^{8}$.

Wprowadzenie pojęcia pograniczności dyskursów zamiast transdyscyplinarności zaproponował Paweł Dybel (IFiS PAN). Podkreślił, że dyskursy poszczególnych dyscyplin rozwijają się w ciągłej „interakcji” ze sobą, splatając

4 Por. Z. Kloch, Interdyscyplinarność w naukach humanistycznych, w: „Interdyscyplinarność w naukach społecznych i humanistycznych — doświadczenia i projekty" (www.ifispan.waw.pl).

${ }^{5} \mathrm{~J}$. Banaszkiewicz, wystąpienie na konferencji „Interdyscyplinarność w naukach społecznych i humanistycznych — możliwości i ograniczenia”, 21 XI 2007.

6 W. Bolecki, wystąpienie na konferencji „Interdyscyplinarność w naukach społecznych i humanistycznych - możliwości i ograniczenia”, 21 XI 2007.

7 M. Soin, wystąpienie na konferencji „Interdyscyplinarność w naukach społecznych i humanistycznych - możliwości i ograniczenia”, 21 XI 2007.

8 L. Koczanowicz, Interdyscyplinarność między rabunkiem a dialogiem, wystąpienie na konferencji „Interdyscyplinarność w naukach społecznych i humanistycznych - możliwości i ograniczenia”, 9 I 2008. 
się, oddalając, znowu splatając $\mathrm{w}$ zależności od potrzeb przedmiotu opisu. Jako przykłady mogą tu posłużyć dyskursy współczesnych przedstawicieli myśli socjologicznej: Habermasa, Honnetha, Giddensa, Bourdieu, Baudrillarda, Baumana. Ich dyskurs „często celowo «dryfuje» na pograniczu różnych dyscyplin, zawierając w sobie elementy dyskursu filozoficznego, kulturoznawczego, psychoanalitycznego, antropologicznego, teorii prawa czy nawet filologii" 9 .

Zwrócenia uwagi wymaga krytyczne podejście do badań interdyscyplinarnych zaprezentowane przez Szymona Wróbla (IFiS PAN), który podkreślił ich pozorność i wręcz niemożność prowadzenia. Istota problemu, jego zdaniem, tkwi w alternatywie: albo jedność nauki jest nie do utrzymania, albo da się ją utrzymać. Strony alternatywy niosą poważne konsekwencje dla interdyscyplinarności. Jeżeli przyjmiemy tezę pierwszą i założymy, że dyscypliny naukowe posługują się odrębnymi językami i metodami, to współpraca między nimi jest niemożliwa. Jeżeli przyjmiemy tezę drugą, to interdyscyplinarność staje się problemem pozornym, gdyż pozorna jest autonomia poszczególnych dyscyplin ${ }^{10}$.

\section{ROZUMIENIE INTERDYSCYPLINARNOŚCI: PRÓBY OKREŚLENIA POJĘCIA I ZADAŃ}

Interdyscyplinarność to zarówno wykraczanie poza daną dyscyplinę, tę, którą reprezentuje badacz, jak i rozpatrywanie określonego tematu z różnych perspektyw. Na przykład językoznawcy slawiści, zajmując się problemem języków mniejszościowych, w swoich pracach wkraczają na grunt etnologii, kulturoznawstwa czy socjologii. Czy jest to podejście interdyscyplinarne czy jednak pewne nadużycie? Istnieje potrzeba dodefiniowania pojęcia interdyscyplinarności, czy chodzi o metodę, praktykę badawczą, zespół przeświadczeń na temat świata, przedsądów.

Konieczność zastanowienia się nad rozumieniem interdyscyplinarności właściwym różnym dyscyplinom naukowym podkreśliła Joanna Kurczewska (IFiS PAN). Jej zdaniem, warto zastanawiać się nad zadaniami interdyscyplinarności, nad możliwościami badań interdyscyplinarnych i ich ograniczeniami, jak również nad sytuacjami, w których sięga się po interdyscyplinarność. Warto pytać o genealogię interdyscyplinarności i o jej przyszłość, warto przemyśleć relacje między koncepcjami transdyscyplinarności, multidyscyplinarności i interdyscyplinarności. Jest to temat istotny dla praktyki badawczej, teorii społecznej, a także praktyki edukacyjnej.

Bardzo istotne pytanie postawił Wojciech Łukowski (SWPS, INP UW): czy możliwe jest podejście interdyscyplinarne definiowane jako pewna zdolność,

\footnotetext{
${ }^{9}$ P. Dybel, Dyskursy „metodyczne” $i$ „pograniczne” w socjologii wspótczesnej, w: „Interdyscyplinarność w naukach społecznych i humanistycznych: doświadczenia i projekty" (www.ifispan.waw.pl).

$10 \mathrm{Sz}$. Wróbel, Interdyscyplinarność jako efekt dyscyplinarności, w: „Interdyscyplinarność w naukach społecznych i humanistycznych — doświadczenia i projekty” (www.ifispan.waw.pl).
} 
umiejętność, a w zasadzie nawet rodzaj techniki badawczej, polegającej na spojrzeniu na obiekt $z$ perspektywy kilku lub kilkunastu dyscyplin badawczych, czemu towarzyszy zdolność do podejścia zgeneralizowanego? Jednocześnie odpowiedzi wymaga pytanie: co taka interdyscyplinarność mogłaby oznaczać w praktyce badawczej? ${ }^{11}$

Należy zwrócić uwagę na podjętą przez Zbigniewa Klocha (IBL PAN) i Daniela Grinberga (Uniwersytet w Białymstoku) próbę określenia zadań interdyscyplinarności oraz pozytywnego zdefiniowania pojęcia interdyscyplinarności. Interdyscyplinarność to rezultat prac zespołowych przedstawicieli różnych dziedzin wiedzy, pracujących nad tym samym tematem, tworzących pewną syntezę, co jest właśnie celem tego typu badań. Istotne jest, aby współpracując nad rozwiązaniem jakiegoś problemu, podjąć dyskusję, wypracować jakąś wartość dodaną. Jednakże czy w interdyscyplinarności rzeczywiście chodzi o syntezę? Czy o wymianę?

Zdaniem Barbary Fatygi (ISNS UW), interdyscyplinarność można rozpatrywać w dwojaki sposób - jako „projekt edukacyjny i proces trajektoryjny”. Interdyscyplinarne projekty edukacyjne są realizowane $\mathrm{w}$ polskich uczelniach dość rzadko. Jeśli już powstanie jakaś nowa interdyscyplinarna instytucja naukowa, czy też nowy kierunek studiów, to jego twórcy zaraz określają granice, aby oddzielić się, wyodrębnić, pokazać swoją inność. W rezultacie to, co powstało na pograniczach dyscyplin, samo staje się dyscypliną czy subdyscypliną ${ }^{12}$. Jest to jeden $z$ problemów, jakie napotykają na swojej drodze interdyscyplinarne projekty badawcze - nie potrafią one oprzeć się „zinstytucjonalizowanemu i instytucjonalizującemu się procesowi dydaktycznemu" ${ }^{13}$. W nauce powszechny jest, według Barbary Fatygi, model sztywnych dyscyplin, a nie niewygodny dla zinstytucjonalizowanej nauki model swobodnie poszukujących wiedzy wspólnot uczonych i uczących. Jako przykład procesu trajektoryjnego Barbara Fatyga podała własną biografię, podobnie mówiąc o doświadczeniu dydaktycznym wskazała na prowadzone przez siebie w Instytucie Stosowanych Nauk Społecznych zajęcia „Interdyscyplinarne problemy humanistyki".

Na dwojaki charakter interdyscyplinarności zwróciła uwagę również Anna Zeidler-Janiszewska (SWPS), wskazując na: perspektywiczne badanie tego samego problemu lub konstruowanie nowego problemu. Mam duże wątpliwości,

11 W. Łukowski, wystąpienie na konferencji „Interdyscyplinarność w naukach społecznych i humanistycznych — możliwości i ograniczenia”, 10 XII 2007.

12 B. Fatyga, Interdyscyplinarność jako projekt edukacyjny $i$ jako proces trajektoryjny, w: „Interdyscyplinarność $\mathrm{w}$ naukach społecznych i humanistycznych — doświadczenia i projekty" (www.ifispan.waw.pl).

$13 \mathrm{~W}$ wystąpieniu autorka podkreślała, że pojęć procesu edukacyjnego i procesu dydaktycznego nie używa zamiennie: pierwsze jest zdecydowanie szersze (obejmujące również samokształcenie i swobodne poszukiwania); drugie rozumie jako przekazywanie „nauczanym” usystematyzowanej (w pewien sposób kanonicznej) wiedzy z zakresu danej dyscypliny. 
czy rzeczywiście trafna $\mathrm{w}$ tym kontekście jest sformułowana przez Zbigniewa Klocha propozycja nazwania tego typu podejść mianem badań transdyscyplinarnych, a nie interdyscyplinarnych. Warto byłoby pochylić się nad etymologią pojęć „interdyscyplinarność”, „transdyscyplinarność”, „multidyscyplinarność”.

\section{SOCJOLOGIA I HISTORIA: TRUDNE ZWIĄZKI}

Pogranicze między socjologią a historią to szczególne pogranicze i szczególna interdyscyplinarność. W socjologii daje się zauważyć rosnące zainteresowanie historią, wręcz uhistorycznienie badań socjologicznych. Agnieszka Kolasa-Nowak (IS UMCS) miała jednak wątpliwości, czy przenikanie analiz historycznych do badań socjologicznych to już przejaw interdyscyplinarności, czy jedynie dyletanckie zajmowanie się historią. Tezę o uhistorycznieniu socjologii podał w wątpliwość Daniel Grinberg. Jego zdaniem, nie widać ani szczególnego rozwoju, ani popularności socjologii historycznej, zarówno w Polsce, jak i na świecie. W badaniach socjologicznych występują pewne ciche założenia historyczne, jednakże brak wypracowanych metod. Na odwrotną relację między socjologią a historią i innymi dyscyplinami zwrócił uwagę Mirosław Chałubiński (WNP AH), który dostrzega powszechny wpływ socjologii, tzw. usocjologicznienie badań naukowych.

Socjologia, a konkretnie socjologia wiedzy, dopóty wchodzi w obszar zainteresowań historii idei, dopóki ta zachowuje swój interdyscyplinarny charakter, gdy jednak historia idei zaczyna się profesjonalizować, to socjologia staje się pierwszą dyscypliną „do odstrzału”. Przykładu takiego procesu dostarcza, zdaniem Andrzeja Waśkiewicza (IS UW), koncepcja historii myśli politycznej Quentina Skinnera i J. G. A. Pococka.

Związki socjologii z innymi dyscyplinami, zwłaszcza relacje socjologia-historia, stały się tematem burzliwej dyskusji. Próby odpowiedzi tworzyły rodzaj kontinuum — od twierdzeń, że historia nie odnosi pożytków z socjologii (Andrzej Waśkiewicz) do diagnoz o usocjologicznieniu widocznym w wielu dyscyplinach (Mirosław Chałubiński), jak również od tez o uhistorycznieniu socjologii (Agnieszka Kolasa-Nowak) do diagnozy braku badań historycznych w socjologii (Daniel Grinberg). Sądzę, że tak wielkie zróżnicowanie poglądów jest uwarunkowane orientacją naukową ich nosicieli - Kolasa-Nowak zajmuje się socjologią historyczną, Grinberg reprezentuje historię, Waśkiewicz jest historykiem, a Chałubiński socjologiem. Zastanawiający w tym kontekście jest fakt, jak odmiennie patrzy się na socjologię w zależności od dyscypliny, którą się reprezentuje, oraz miejsca, w którym jest się zatrudnionym.

\section{FILOZOFIA I SOCJOLOGIA: CIĄGŁOŚĆ PERSPEKTYW?}

Powrócę jeszcze do problemów pogranicz między dyscyplinami. Bardzo ważne jest pogranicze filozofii i socjologii. Do problemu relacji między nimi 
musi się ustosunkować każdy filozof i każdy socjolog. Sięgając po przykład miejsca, w którym odbywał się panel, Joanna Kurczewska stwierdziła, że w Instytucie Filozofii i Socjologii PAN filozofowie i socjologowie zawsze zastanawiali się, co mają ze sobą wspólnego, czy istnieją jakieś wspólne problemy, nad którymi mogliby pracować, czy posługują się wspólnym słownikiem pojęciowym, jakie relacje ich łączą, czy jest im do siebie bliżej czy dalej, czy warto być razem, czy może oddzielnie. Nieustannie trwają dyskusje na temat coraz większej złożoności filozofii i socjologii, coraz większej potrzeby przemyślenia, zwłaszcza przez socjologów, relacji z dyscypliną, z którą złączeni są w ramach jednej instytucji.

Kwestia odrębności i podobieństwa jako kryterium możliwości badań interdyscyplinarnych pojawiła się w wielu wystąpieniach, dla jednych odrębność była przeszkodą we współpracy, dla innych ją umożliwiała.

Zadałam sobie pytanie, podobnie jak inni uczestnicy obrad, jaka jest geneza odrębności filozofii i socjologii? Czy przyczyną jest to, że filozofia jest nauką spekulatywną, a socjologia empiryczną, czy stąd wynikają różnice? Taki podział, zdaniem Józefa Niżnika (IFiS PAN), ignoruje wszystko, co na temat nauki powiedziała filozofia nauki. Nieprzekonująca jest dla mnie dalsza argumentacja tego filozofa, że odrębność filozofii i socjologii wynika z faktu, iż socjologia na świecie, zwłaszcza w Stanach Zjednoczonych, zinstytucjonalizowała się jako nauka empiryczna, behawioralna, odcinając się całkowicie od humanistyki i swoich źródeł, a stamtąd trafiła do Polski. Zastanawiając się nad rozdziałem filozofii i socjologii należy spojrzeć głębiej, na historię, na metodologię i tam zobaczyć właśnie nie rozdział, ale ścisły związek między filozofią a socjologią. Zapomina się o dyscyplinach granicznych, takich jak socjologia wiedzy, socjologia nauki, historia idei. Problematyka tych nauk jest filozoficzna i socjologiczna zarazem. Socjologia potrzebuje filozofii, potrzebuje jej dlatego, że zrywając $z$ dyskursem filozoficznym, staje się nauką jałową, wiedzą $\mathrm{w}$ cudzysłowie, produkującą trywialne opisy rzeczywistości społecznej ${ }^{14}$.

Tezę o jakościowej różnicy między perspektywą filozoficzną a socjologiczną, która jest trudna do pokonania, a może jej przekroczenie jest wręcz niemożliwe, postawił Robert Piłat (IFiS PAN). Jego zdaniem, między tymi podejściami występuje teoretyczna niewspółmierność, jednocześnie łączy je racjonalny, oparty na poznawczej motywacji związek ${ }^{15}$. Ponieważ ingerują głęboko w sam przedmiot badań i w treść stawianych pytań, trzeba zachować dużą ostrożność $\mathrm{w}$ przenoszeniu idei z jednej dyscypliny do drugiej. I jeżeli przejścia między tymi perspektywami nie są oczywiste, są skokowe, nieciągłe, to jednak warto się zastanowić, co możemy zrobić, aby pogłębić struktury tych przejść, aby były

14 J. Niżnik, wystąpienie na konferencji „Interdyscyplinarność w naukach społecznych i humanistycznych - możliwości i ograniczenia", 9 I 2008.

${ }^{15}$ R. Piłat, Socjologia i filozofia - niewspótmierność perspektyw, w: „Interdyscyplinarność w naukach społecznych i humanistycznych — doświadczenia i projekty” (www.ifispan.waw.pl). 
bardziej zrozumiałe ${ }^{16}$. Sądzę, że gdybyśmy byli zbyt ostrożni, gdyby badacze nie stawiali ryzykownych hipotez, nie łączyli perspektyw, to być może nigdy nie doszlibyśmy do ciekawych rezultatów badawczych, nigdy nie powstałyby pewne koncepcje, na przykład Pierre'a Bourdieu czy Chantal Mouffe.

Nie podjęto jednak próby znalezienia modus vivendi między niewspółmiernością perspektywy filozoficznej i socjologicznej a perspektywą jedności filozofii i socjologii. Kwestia ta podzieliła uczestników seminarium.

Możliwość współpracy czy też jej brak wynika ze sposobu widzenia relacji filozofii i socjologii. Zdawałoby się, że jeżeli dyscypliny te są oddzielone, współpracować jest trudniej, a jeżeli wychodzi się z założenia o wspólnych korzeniach filozofii i socjologii, to współpraca jest łatwiejsza. Radosław Sojak (IS UMK) zaprzeczył tej generalizacji, stawiając tezę, że to odrębność warunkuje możliwość badań interdyscyplinarnych — jeśli dyscypliny są zbyt blisko siebie, ich odróżnienie jest trudne, a zarazem nie leży w polu ich zainteresowań ${ }^{17}$.

Trudności z identyfikacją związków między filozofią a socjologią wynikają $z$ faktu, że nie ma jednej filozofii i jednej socjologii — podkreślił Jerzy Szacki (IFiS PAN). Wielkie dyscypliny nie są całościami - socjologia to konstelacja różnych badań i teorii, które są od siebie niezależne. Podobnie jest w filozofii. Filozofia będzie socjologowi bliska bądź daleka w zależności od tego, jaką socjologię on reprezentuje. Także na gruncie samej socjologii istnieją problemy z klasyfikacją koncepcji takich myślicieli jak Hobbes i Weber jako jednoznacznie socjologicznych. Chcąc bowiem dotrzeć do istoty pewnych zjawisk społecznych, należy spojrzeć na nie $z$ wielu perspektyw.

\section{INTERDYSCYPLINARNOŚĆ - DYSCYPLINARNOŚĆ — SPECJALIZACJA}

Dlaczego tak mało pisze się i mówi o interdyscyplinarności, w czym tkwi problem, czy w niezdefiniowaniu poszczególnych pojęć, czy jednak w różnorodności definicji? Interdyscyplinarność i związane z nią problemy to konsekwencja ściśle uniwersyteckiego sposobu podziału dyscyplin naukowych, zdaniem Szymona Wróbla, jak również charakterystycznej dla tego podziału potrzeby uzasadnienia jedności nauki. Immanentną cechą dociekań naukowych jest specjalizacja, a nie interdyscyplinarność. Pojawia się pytanie, dlaczego dochodzi do podziałów, skoro towarzyszą im tendencje do jednoczenia? Leszek Koczanowicz odpowiedział, że w nauce występują dwa powiązane ze sobą procesy specjalizacji, pierwszy opierający się na oddalaniu dyscyplin od siebie i od filozofii, drugi oparty na ideologii samowystarczalności dyscypliny i zerwaniu więzi z filozofią.

16 J. Brudzińska, wystąpienie na konferencji „Interdyscyplinarność w naukach społecznych i humanistycznych - możliwości i ograniczenia", 9 I 2008.

17 Por. R. Sojak, Czy możliwa jest interdyscyplinarność socjologii i filozofi??, w: „Interdyscyplinarność w naukach społecznych i humanistycznych: doświadczenia i projekty" (www.ifispan.waw.pl). 
W mojej ocenie przeciwstawianie interdyscyplinarności specjalizacji jest wysoce problematyczne. Istotne jest, aby do rozwiązywania konkretnych problemów używać podejścia specjalistycznego bądź interdyscyplinarnego w zależności od potrzeb, a nie trzymać się dogmatycznie jednej perspektywy. Zdaniem Zbigniewa Klocha, nie jest to opozycja poetyk, lecz konsekwencja dopasowania rodzaju badań do założonych celów ${ }^{18}$. Danuta Ulicka (Wydział Polonistyki UW) postawiła tezę, że badania transdyscyplinowe sytuują się między autonomią, interdyscyplinarnością a profesjonalizmem dociekań naukowych. Warunkiem rzetelnych badań jest ich trafność, istotne jest również to, aby badania transdyscyplinowe były współbieżne $z$ badaniami specjalistycznymi ${ }^{19}$.

\section{TYPOLOGIA INTERDYSCYPLINARNOŚCI}

Odbywające się w trakcie całego cyklu spotkań dyskusje, dotyczące zawłaszczania, przejmowania, dostosowywania, pobierania próbek, dobierania, które to działania są nieodłącznymi elementami podejść interdyscyplinarnych, były bardzo żywe. Świadczyć o tym może używanie barwnego języka potocznego, w którym powstał rodzaj typologii interdyscyplinarności. Zostały wyróżnione następujące jej typy: „rabunkowa”, „butikowa”, „dialogowa” (Leszek Koczanowicz), „pływacka” (Tadeusz Gadacz), „eklektyczna”, „integracyjna”, „wycieczkowa” (Anna Zeidler-Janiszewska), „erudycyjna” (Anna Zeidler-Janiszewska, Rafał Wierzchosławski).

Chciałabym zwrócić uwagę na dyskusję na temat pojęcia „interdyscyplinarności rabunkowej": Czy zjawisko to powinno być oceniane negatywnie czy nie? Czy jeśli prowadzi do ciekawych rezultatów, to jest uprawomocnione? Za tą ostatnią możliwością opowiedział się Józef Niżnik, przywołując przykład socjologii fenomenologicznej.

Sądzę, że określanie dokonań Alfreda Schütza mianem interdyscyplinarności rabunkowej jest nieuprawnione. Nie tylko przełożył on pojęcia filozoficzne na socjologiczne, ale zmierzył się także z konsekwencjami takiego przekładu. Socjologia fenomenologiczna jest jak najbardziej pozytywnym przykładem obiegu idei czy podejścia interdyscyplinarnego. Podzielam pogląd Leszka Koczanowicza, że trudno pogodzić się z rabunkiem z dyscypliny, którą się reprezentuje, $z$ przejmowaniem kategorii i pojęć bez pogłębionej refleksji, jednakże zwykle nie mamy oporów, co ciekawe, przed zawłaszczaniem z „cudzych podwórek".

18 Por. Z. Kloch, Interdyscyplinarność w naukach humanistycznych, w: „Interdyscyplinarność w naukach społecznych i humanistycznych — doświadczenia i projekty" (www.ifispan.waw.pl).

19 Danuta Ulicka przypomniała o tym w artykule Autonomia — interdyscyplinarność - profesjonalizm (teoria literatury dawniej $i$ dziś), w: „Interdyscyplinarność w naukach społecznych i humanistycznych — doświadczenia i projekty" (www.ifispan.waw.pl). 
$\mathrm{Z}$ dużym zaangażowaniem dyskutowano też nad wykorzystywaniem dorobku naukowego w sposób nieuprawniony. Wyróżniono takie kategorie jak: „kłusownicy”, „harcownicy” czy „watahy”. Pojęcia wędrujące $z$ dyscypliny do dyscypliny, jak kultura czy trauma, mogą być przywoływane jako przykłady „intelektualnego kłusownictwa” 20 . Obieg idei zaś jest pozorowany przez „harcowników” i „watahy”. Interesująca jest w tym kontekście propozycja Wojciecha Burszty (Instytut Slawistyki PAN, SWPS), by podążać śladem wędrujących pojęć w toku transdyscyplinarnej edukacji.

Chciałabym zwrócić uwagę na propozycję Leszka Koczanowicza — interdyscyplinarności dialogowej, dzięki której możliwy staje się ścisły związek między filozofią i socjologią. Nauki humanistyczne i społeczne zmuszone są do określania swych podstaw $\mathrm{w}$ konfrontacji z założeniami filozoficznymi. „Ten okrężny ruch: założenia filozoficzne - wyniki badań — powrót do założeń, może być zmodyfikowany w obrębie dialogowej interdyscyplinarności. Filozofia staje się wtedy partnerem dialogu, w którym jej pytania stają się kanwą dla odpowiedzi formułowanych przez nauki szczegółowe. Odpowiedzi te wracają do filozofii po to, by mogły zostać przeformułowane stawiane przez nią pytania. Wspólna perspektywa, którą można uzyskać w ten sposób, jest raczej kwestią wymiany niż syntezą teorii i badań empirycznych. Oczywistą koniecznością takiego dialogu jest umiejętność wzajemnego uczenia się języka partnera dialogu i szanowania tego języka jako równoprawnego. Wymaga to odrzucenia pokusy tłumaczenia wszystkiego na swój język i przez to sprowadzanie dialogu do pseudodialogu, czyli akceptacji jednej tylko płaszczyzny poznania przy pozorach porozumienia. [...] Teoria społeczna, wyłaniająca się dyscyplina nauki, może być właśnie takim miejscem dialogu między filozofią a socjologią, o ile nie ulegnie pokusie przyjęcia jedynie jednej wyłącznej płaszczyzny wyjaśnień społecznych zachowań człowieka, ale pozostanie przy założeniach dialogowych, w których pytania filozoficzne staną się ramami dla empirycznych wyników i odpowiadających im teorii" 21 .

\section{„WSPÓŁPRACA” INSTYTUCJONALNA}

Próby współpracy instytucjonalnej, zorganizowanej interdyscyplinarności, a także braki w tym zakresie, rozpatrywano na przykładzie Międzywydziałowych Indywidualnych Studiów Humanistycznych jako udanej próby interdyscyplinarnego kształcenia, klęski europeistyki oraz studiów międzykulturowych, Centrum Badań Interdyscyplinarnych, czasopisma „Ruch Prawniczy, Ekonomiczny i Socjologiczny” oraz naukowej sieci badawczej.

20 J. Burszta, wystąpienie na konferencji „Interdyscyplinarność w naukach społecznych i humanistycznych - możliwości i ograniczenia”, 21 XI 2007.

21 L. Koczanowicz, Interdyscyplinarność między rabunkiem a dialogiem, w: „Interdyscyplinarność w naukach społecznych i humanistycznych — doświadczenia i projekty” (www.ifispan.waw.pl). 
Wbrew wymienionym przykładom Tomasz Żyro (INP UW) podkreślił, że instytucje częściej wymuszają nie współpracę, lecz izolację. Dzielą je mury, nie tylko te fizyczne, jak między Uniwersytetem a PAN-em, ale również te wewnętrzne, psychologiczne pomiędzy poszczególnymi wydziałami tej samej uniwersyteckiej instytucji. Potrzebna byłaby dyskusja nad statusem Uniwersytetu w ogóle, zwłaszcza w obliczu powszechnej demokratyzacji wiedzy. Instytucjonalne związki między filozofią i socjologią stwarzają pewne możliwości, ale ta instytucjonalna bliskość nie gwarantuje synergii.

Interdyscyplinarność jest jednak wymuszana przez rozwój samej nauki. Powstają interdyscypliny, multidyscypliny, transdyscypliny, zarówno w naukach przyrodniczych, jak i humanistycznych. Wbrew potocznej intuicji dużo łatwiej jest porozumieć się przedstawicielom nauk przyrodniczych niż przedstawicielom nauk humanistycznych. Powstały biochemia, biofizyka, astrofizyka, w naukach humanistycznych zaś trudno o „nauki pograniczne” powstające na styku dyscyplin.

Uczestnicy obrad podkreślali, że naukowa sieć badawcza to przykład współpracy przedstawicieli różnych instytucji, wymuszonej za sprawą funduszy przyznawanych na pewne programy, pewne bloki tematyczne, a nie na rozwój dyscypliny. Taką naukową sieć badawczą („Rozpad i nowy porządek. Społeczeństwo — naród - kultura w okresie wielkiej zmiany") tworzy na przykład pięć jednostek naukowych PAN: Instytut Psychologii, Instytut Studiów Politycznych, Instytut Historii, Instytut Badań Literackich oraz Instytut Filozofii i Socjologii. Czy takie działania wymuszą rzeczywistą współpracę? Czy współpracę pozorną?

Zanim zostaniemy skazani instytucjonalnie na praktyki, które można nazwać „zorganizowaną interdyscyplinarnością”, warto, aby interdyscyplinarność stała się przedmiotem namysłu i naszym świadomym wyborem, który „zgadzałby się" z koniecznością.

\section{INTERDYSCYPLINARNOŚĆ I ZAGROŻENIA}

Sądzę, że warto zwrócić uwagę na to, jak wiele obaw budziły zagrożenia, które interdyscyplinarność niesie ze soba, czyli moda na tego typu badania, imperializm dyscyplinarny, kompleksy naukowców, nieporozumienia pojawiające się na styku dyscyplin.

Uważam, że moda na interdyscyplinarność stanowi zagrożenie dla rzeczywistych badań interdyscyplinarnych. Zagrożeniem jest „badana sałatka”, o której wspomniał Daniel Grinberg, do czego w swoim wystąpieniu nawiązał również Dariusz Kołodziejczyk (Wydział Historyczny UW). Modne jest obecnie zajmowanie się kwestiami interdyscyplinarnymi, na przykład genderowymi. Relatywnie łatwo jest dostać grant na tego typu badania, podobnie jak kiedyś łatwo było dostać pieniądze na badania nad klasą robotniczą. Istnieje jednak niebezpieczeństwo, że w dużej liczbie osób podejmu- 
jących popularne badania wielu jest karierowiczów i miałkich intelektualistów.

Chciałabym podkreślić, że zagrożeniem jest sposób podejścia do badań interdyscyplinarnych - to, jak traktujemy interdyscypliny. Czasem motywem jest pasja, czasem konieczność rozwiązania konkretnego problemu, czasem jest to sposób na zarobienie pieniędzy. Na badania interdyscyplinarne można dostać bardzo interesujące granty, toczą się wokół nich interesujące dyskusje, niekiedy jednak jest wręcz odwrotnie - jeśli badań, jakiegoś ujęcia, nie możemy podporządkować określonej dyscyplinie, wnioskodawca jest odsyłany od jednej komisji do drugiej z pytaniem, dlaczego z takimi badaniami przychodzi do filozofów, a nie socjologów lub odwrotnie, nie ma przecież komisji interdyscyplinarnej.

Sądzę, że w Polsce powszechny jest taki model interdyscyplinarności, zgodnie $z$ którym badacz wychodzi od wymogów konkretnej dyscypliny, na przykład socjologii, i tworzy interdyscyplinarny program badawczy, dotyczący na przykład czasu — wtedy może uprawiać badania interdyscyplinarne. Jeśli natomiast wychodzi od interdyscyplinarności, odwołując się do dwóch czy trzech dyscyplin „bazowych”, na przykład filozofii i socjologii, lub jeszcze psychologii, i jest autorem rozprawy doktorskiej, której tematem jest czas rozpatrywany w wielości tych perspektyw, to na trudności z obroną takiego doktoratu, choćby z powodu tak prozaicznego pytania: a gdzie chcesz mieć obronę, na filozofii czy socjologii?

Nasuwa się pytanie: czy wynika to z ograniczeń instytucjonalnych, nadmiernej specjalizacji, sztywnych klasyfikacji KBN-owskich, z biurokratycznych ograniczeń nauki, czy też warto poszukać głębszych uwikłań tego problemu, aby poszukujący naukowcy i studenci mogli znaleźć dla siebie miejsce w ramach instytucji, a nie poza nimi?

Zdaniem niektórych uczestników dyskusji istnieje potężny nurt sprzeciwu wobec interdyscyplinarności. Jednak wszyscy chcą wydać się interdyscyplinarni, nie chcą się przyznać do bycia przeciw. Twierdzą, że bardzo dobrze, $\dot{z}$ e istnieją badania interdyscyplinarne, że łączy się perspektywy, że mamy dyscypliny pograniczne, będąc $w$ istocie przekonani, że można być „fachowcami” jedynie $\mathrm{w}$ wąskiej dziedzinie. Taki fałszywy poklask stwarza duże zagrożenie dla interdyscyplinarności, gdyż w sposób ukryty hamuje rozwój nauk.

\section{BADANIA INTERDYSCYPLINARNE A MOŻLIWOŚCI BADACZA}

Problemy z prowadzeniem badań interdyscyplinarnych uwarunkowane są również możliwościami badaczy. Ekspertem można być jedynie w określonej dziedzinie wiedzy. Jeśli komuś uda się coś więcej, przekroczyć granice własnej dyscypliny, to naraża się na zarzut bycia niekompetentnym, zarówno w dziedzinie, w której jest ekspertem, jak i w tej, do której wkracza. Czy można sobie wyobrazić socjologa specjalistę od młodzieży, który jednocześnie byłby 
specjalistą w zakresie problematyki ludzi starszych? Teoretycznie jest możliwa „interdyscyplinarność źródłowa”, ale wymaga ona bardzo dużego nakładu pracy. Łatwiejsze jest osiągnięcie „interdyscyplinarności myślowej”, jak nazwał to Marian Golka (IS UAM). Polega ona na szukaniu interpretacji, relacji między zjawiskami, wtedy interdyscyplinarność jest wręcz pożądana ${ }^{22}$. W moim przekonaniu ważne jest, aby być „ekspertem źródłowym”, jednakże być może ważniejsze jest bycie „poszukiwaczem myślowym”.

Chciałabym też zwrócić uwagę na problem tożsamości zawodowej. Łatwiej jest ją utrzymać, kiedy deklaruje się przynależność do jednej dyscypliny, choć ten sam badacz raz będzie się przedstawiał jako specjalista socjolog narodu, innym razem jako prowadzący badania interdyscyplinarne, z wykorzystaniem dorobku socjologii, filozofii, historii idei, psychologii czy etnologii, poświęcone kwestii narodu. Uzależnione jest to od sytuacji.

\section{BIOGRAFIE}

Zaskakująco interesujące i ważne okazały się wątki autobiograficzne wplatane $\mathrm{w}$ dyskusję. Uczestnicy mówili o własnych uwikłaniach $\mathrm{w}$ problemy interdyscyplinarności, co było potwierdzeniem stawianej przez wielu tezy o podejściu interdyscyplinarnym jako „naturalnym nastawieniu” naukowca. Wybór jest oczywisty - jeśli chcemy się rozwijać, to musimy wychodzić poza granice własnych wąskich specjalności, choć może to wiązać się z wieloma trudnościami.

Podejście interdyscyplinarne w nauce jako „naturalne nastawienie” badacza to temat bardzo bliski wielu ludziom nauki. Małgorzata Fuszara, z wykształcenia socjolog i prawnik (ISNS UW), socjologię prawa i gender studies określiła jako dwa pola zainteresowań. Socjologii prawa warto przyglądać się z interdyscyplinarnego punktu widzenia. Placówki socjologii prawa są zarówno na wydziałach prawa, jak i na wydziałach socjologii. Warto obserwować, jak do tej samej materii podchodzą socjologowie, którzy uprawiają socjologię prawa, a jak prawnicy, którzy zajmują się tą dyscypliną, kiedy pojawiają się inne pytania $i$ inaczej podchodzi się do odpowiedzi.

Z własnego doświadczenia wiem, że niekiedy trudno pracować nad problemami interdyscyplinarnymi. Mówiąc o kłopotach z obroną doktoratu, który nie mieści się w konkretnej dyscyplinie, Leszek Koczanowicz odwołał się do własnej biografii. Ukończył studia magisterskie z psychologii, a doktoryzował się w Instytucie Filozofii Uniwersytetu Wrocławskiego. Jego rozprawa doktorska z punktu widzenia psychologów była zbyt filozoficzna, filozofowie zaś

22 M. Golka, Potrzeby i trudności multi- $i$ interdyscyplinarności, wystąpienie na konferencji „Interdyscyplinarność w naukach społecznych i humanistycznych - możliwości i ograniczenia", 21 XI 2007. 
twierdzili, że jest za bardzo psychologiczna, wreszcie promotorem został Jerzy Szacki - socjolog.

Wątki biograficzne pojawiły się również w wystąpieniach Anny Zeidler-Janiszewskiej i Katarzyny Rosner. Anna Zeidler-Janiszewska, filozof i polonista, zastanawiając się nad swoimi uwikłaniami w interdyscyplinarność, mówiła, że wychodząc od polonistyki przez filozofię dotarła do kulturoznawstwa ${ }^{23}$. Katarzyna Rosner, filozof, zajmuje się filozofią kultury (IFiS PAN), również odniosła się do własnej drogi zawodowej, którą zaczęła od historii literatury polskiej, była teoretykiem literatury, estetykiem, filozofem. Po części wynikało to $z$ ewolucji zainteresowań, po części ze świadomości, że pewne dyscypliny $z$ upływem czasu stają się martwe, nie pozwalają na stawianie naprawdę ciekawych pytań.

Ogólne spojrzenie na wystąpienia panelowe i głosy, które padły podczas dyskusji w cyklu seminariów „Interdyscyplinarność w naukach społecznych i humanistycznych - możliwości i ograniczenia”, pozwala stwierdzić, że zdecydowana większość $z$ nich sytuuje się $w$ dwóch nurtach, opowiadania się za interdyscyplinarnością jako immanentną cechą dociekań naukowych oraz optowania za specjalizacją jako charakterystycznym rysem badań. Dyskusji został poddany problem relacji interdyscyplinarność-dyscyplinarność czy interdyscyplinarność-specjalizacja - jako cecha zarówno dyscyplin naukowych, jak i jednostkowego doświadczenia. Czy jest to opozycja czy kontinuum? A może triada autonomia-interdyscyplinarność-profesjonalizm? Głosy w tej kwestii były podzielone.

Warto zwrócić uwagę na problemy towarzyszące pozycji osoby prowadzącej badania, która staje przed dylematem: być wyspecjalizowanym ekspertem czy zajmować się problemem całościowo. $Z$ jednej strony ktoś, kto pełni taką funkcję, musi wykraczać poza ramy własnej dyscypliny, poszukując rozwiązań problemów, które nie są możliwe do zbadania tylko na jej gruncie, z drugiej - powinien trzymać się granic własnej specjalności, by nie zostać oskarżonym o herezję, by nie narazić się na zarzut bycia laikiem, a nie ekspertem.

Sądzę, że badacz musi posiąść umiejętność balansowania między tymi skrajnościami, choćby dlatego, że wiele problemów naukowych nie może być rozwiązanych przy użyciu jedynie wąskiej perspektywy właściwej dla określonej dyscypliny naukowej.

23 Anna Zeidler-Janiszewska wystąpiła w panelu trzecim, jednak podjęta przez nią próba określenia, czym jest dyscyplinarność, wielodyscyplinarność, transdyscyplinarność, tematycznie sytuuje jej wypowiedź w panelu pierwszym. Instytuty Kulturoznawstwa we Wrocławiu, Łodzi, Poznaniu, które powstawały na przełomie lat sześćdziesiątych i siedemdziesiątych, to przykłady, jej zdaniem, instytucji badań interdyscyplinarnych. 
Związki socjologii z różnymi dyscyplinami, w szczególności z historią i filozofią, okazały się - jak oczekiwano - tematem bardzo istotnym. Uwagę zwracano $z$ jednej strony na ich nieunikniony charakter, pojawiły się tezy o uhistorycznieniu badań socjologicznych, a także o socjologizacji innych nauk, a $z$ drugiej - na trudności z tym związane, na przykład niewspółmierność teoretyczną.

Jednakże współpraca różnych środowisk naukowych niesie ze sobą wiele problemów, ich przedstawiciele nie są gotowi do wspólnych działań, nie przywykli do prowadzenia badań interdyscyplinarnych. Na przykład rozważanie problemów natury ludzkiej jest przedmiotem zarówno psychologii społecznej, jak i psychologii międzykulturowej, ale przedstawiciele obu dyscyplin nie znają wzajemnie swoich prac i osiągnięć, a co za tym idzie - nie korzystają z nich. Próby zinstytucjonalizowania współpracy również nie przynoszą oczekiwanych rezultatów.

Zastanawiający, jak sądzę, w tym kontekście jest fakt, dlaczego pewne instytucje odnoszą sukces, a inne porażkę. Jakie warunki muszą zostać spełnione? Dlaczego jedni dążą do syntezy, a inni do wymiany? Dlaczego w jednych przypadkach zwycięża model sztywnych dyscyplin, wygodny dla zinstytucjonalizowanej nauki, a w innych model wspólnoty badawczej? Czy interdyscyplinarność to kwestia budowania nowych instytucji czy potrzeba intelektualna? A może „naturalne nastawienie” naukowca? Chcę podkreślić, że te pytania, tak jak wiele innych, pozostały bez odpowiedzi, co oczywiście nie pozwala na zadowolenie ze stanu dyskusji, jednak - co istotne i na czym organizatorom szczególnie zależało - pierwszy krok został zrobiony. Trzy seminaria rozpoczęły w środowisku naukowym dyskusję, która stała się faktem społecznym. Jest to punkt wyjścia do dalszych dyskusji i do dalszych prac.

\section{CO DALEJ?}

Znakomite uzupełnienie podjętych rozważań nad problemami interdyscyplinarności w naukach społecznych i humanistycznych oraz następny krok w dyskusji stanowi wielokrotnie wyżej cytowana internetowa publikacja „Interdyscyplinarność w naukach społecznych i humanistycznych - doświadczenia i projekty". Rozpoczęte podczas cyklu seminariów dyskusje znalazły tam swoje miejsce, a także kontynuacje. Publikacja bowiem nie jest jedynie odzwierciedleniem wystąpień podczas spotkań seminaryjnych. Do udziału zostały zaproszone również osoby, które $z$ różnych powodów nie mogły być na nich obecne, a ci, którzy brali udział w panelach, w formie pisemnej mogli wypowiedzieć się szerzej czy poruszyć problemy, które uznali za ważne, a które nie były dyskutowane ${ }^{24}$.

24 Tom obejmuje 25 artykułów autorstwa: Dominika Bartmańskiego, Jagny Brudzińskiej, Izabelli Bukraby-Rylskiej, Zbigniewa Drozdowicza, Pawła Dybla, Andrzeja Gniazdowskiego, Mariana 
Interdyscyplinarność - moda, konieczność, potrzeba intelektualna, immanentna cecha badań, możliwość, powinność instytucjonalna? Wszystkie te określenia pojawiły się $\mathrm{w}$ trakcie spotkań seminaryjnych. Jednakże te próby ujęcia problemu, moim zdaniem, można określić jako początek, szkic do dalszych poszukiwań. Pytania rozesłane przez organizatorów, a także te, które pojawiły się podczas dyskusji, wyznaczają swego rodzaju program wymagający przyszłych badań. Jedyną propozycją już dopracowaną okazała się koncepcja interdyscyplinarności dialogowej zaproponowana przez Leszka Koczanowicza. Przy ocenie całego przedsięwzięcia posłużę się słowami Jadwigi Zieniuk, która podkreśliła wartość konferencji interdyscyplinarnych, gdyż, jej zdaniem, bardzo istotna jest możliwość poznania punktów widzenia przedstawicieli innych dyscyplin, wieloperspektywiczność, na którą jako organizatorzy bardzo liczyliśmy. Moim zdaniem, bardzo istotny i wart podkreślenia jest fakt, że osoby uczestniczące $\mathrm{w}$ panelach i zabierające głos w dyskusji stworzyły grunt, który pozwala kontynuować rozważania o interdyscyplinarności. Trzy seminaria to początek dyskusji, takie też było założenie organizatorów.

Golki, Barbary Fatygi, Jarosława Kiliasa, Zbigniewa Klocha, Leszka Koczanowicza, Agnieszki Kolasy-Nowak, Joanny Kurczewskiej, Andrzeja Ledera, Magdy Lejzerowicz, Barbary Markowskiej, Roberta Piłata, Macieja Soina, Radosława Sojaka, Jadwigi Staniszkis, Tadeusza Szawiela, Danuty Ulickiej, Andrzeja Waśkiewicza, Rafała Wierzchosławskiego, Szymona Wróbla. 